\title{
The Adequateness of Adaptive Reuse Pre-War Shop houses in Petaling Street for Modern Users
}

\author{
Shahrul Yani Said1', Jonny Wongso², Fatin Najmee Mohd Tahir ${ }^{1}$, \\ Muhammad Edaufi Firdaus Mohd Ni'man ${ }^{1}$ \\ ${ }^{1}$ Centre for Postgraduate Studies, Faculty of Architecture, Planning and Surveying, Universiti Teknologi MARA, Malaysia \\ ${ }^{2}$ Department of Architectural Engineering, Faculty of Civil Engineering and Planning, Universitas Bung Hatta, Indonesia \\ shahrulyani@uitm.edu.my, jonnywongso@bunghatta.ac.id, fatinnajmeemt@yahoo.com, edaufi_1991@yahoo.com \\ Tel: +60104241563
}

\begin{abstract}
Adaptive reuse is seen as a problem-solving alternative to save our old heritage buildings. The research study the adequateness of the adaptive reuse scheme on Pre-War Shop-Houses in Petaling Street to achieve the Quality of Life (QoL) of modern users. This study investigates the requirement, concept, criteria and element of adaptive reuse required by the local authority by observing the conditions of three selected shophouses in Petaling Street. The study results show that the stakeholders understand and comply with local authority's the requirement. The conservation and preservation protect the architectural and historical significance while retaining the pre-war shophouses' identity.
\end{abstract}

Keywords: Adaptive re-use, Petaling Street, Pre-war shophouses, conservation of buildings

eISSN: 2398-4287@ 2021. The Authors. Published for AMER ABRA CE-Bs by e-International Publishing House, Ltd., UK. This is an open access article under the CC BYNC-ND license (http://creativecommons.org/licenses/by-nc-nd/4.0/). Peer-review under responsibility of AMER (Association of Malaysian Environment-Behaviour Researchers), ABRA (Association of Behavioural Researchers on Asians/Africans/Arabians) and CE-Bs (Centre for Environment-Behaviour Studies), Faculty of Architecture, Planning \& Surveying, Universiti Teknologi MARA, Malaysia.

DOI: https://doi.org/10.21834/ebpj.v6i16.2686

\subsection{INTRODUCTION}

Today, the historical building and area are being forgotten and replaced to give new development and commercialisation, even though many preservation and enthusiasts (Teng, 2018). According to UNESCO (2019), the heritage building is a tangible human-made environment with its cultural significance where it can be passed down to future generations through building heritage conservations. Besides preserving the cultural value and understanding our history, the protection of the heritage building can also improve our understanding of how the past built environment can fit today's and future demand (Basha, 2016). The conservation involves technical activity in protecting the fabric and materials of the building. At the same time, it can prolong the building's life hence protect it from decay (Harun, 2011). The conservation involves a minimum intervention and maintains as much as its authenticity. The rehabilitation or adaptive reuse comply with all these terms by acknowledges the need to alter after the building to meet continuing or changing its use while the historic character is retained (WBDG, 2019)

According to Shishavan \& Shihavan (2013), preserving and reusing historic building have a long-term benefit for the one who values them. Proper adaptive reuse helps restore the building's heritage value, allows the place to sustain itself in today's environment, and gives the area a chance to act as social interaction for the community to interact. Adaptive reuse is the process in which it helps in repurposing an old building for modern need while retaining its historical value (Teng, 2018). It was the best approach to minimise the urban sprawl, conserve the existing resources while maintaining the built environment.

eISSN: 2398-42870 2021. The Authors. Published for AMER ABRA cE-Bs by e-International Publishing House, Ltd., UK. This is an open access article under the CC BYNC-ND license (http://creativecommons.org/licenses/by-nc-nd/4.0/). Peer-review under responsibility of AMER (Association of Malaysian Environment-Behaviour Researchers), ABRA (Association of Behavioural Researchers on Asians/Africans/Arabians) and cE-Bs (Centre for Environment-Behaviour Studies), Faculty of Architecture, Planning \& Surveying, Universiti Teknologi MARA, Malaysia.

DOI: https://doi.org/10.21834/ebpj.v6i16.2686 
Much adaptive reuse applied in Malaysia, such as in George Town, Malacca, Kuala Lumpur and many more. For instance, the typology in the building in Kuala Lumpur varies from the government building to hotels, town and shophouses (Basha, 2016). Petaling Street in Kuala Lumpur is chosen as a case study for this research. The adaptive reuse in Klang Valley, especially Petaling Street, gives a life that transformed the shophouses into a trendy and urban concept (Teng, 2018).

The adaptive reuse or changing the building's usage has become the way of life where it becomes fashionable these days. For instance, the consumers will spread the word if they visited the new place that has been converted from an old factory, hotel, brothel and such. Apart from rescuing the old building, it shows the creativity to which they change the old building's interior design to modern design while retaining the exterior architecture (Shazwan, 2016). The pre-war shophouses in Petaling Street changed its function of shop, brothel, hotel and also café.

This adaptive reuse can bring back Petaling Street's glory as a shopping district with a lively and vibrant night market with hundreds of stalls on those days. Hence, this adaptive reuse helps Petaling Street maintain its functions and manage to survive in the future. Other than Chocha Foodstore, there are also Merchant's Lane, PS150, Leaf \& Co Café and Mingle Cafe, the food and beverage outlets housed in century-old shophouses.

This research investigates the application of adaptive reuse schemes in Petaling Street to help retain its heritage built environment and cultural significance and maintain the identity of Petaling Street. The objectives are to explore the authorities' requirement, concept, criteria, and element of adaptive reuse (Department of National Heritage and Kuala Lumpur City Hall). It is also to observe the conditions of adaptive reuse content been followed and comply by the pre-war shophouses owner of Petaling Street and assess the user's perception of the changes and how it affected their modern lifestyle.

\subsection{LITERATURE REVIEW}

\subsection{Adaptive reuse}

Adaptive reuse or rehabilitation is the process of taking off an old building and changing it for other purposes, and reusing it other than its existing users. Based on the Australian ICOMOS Charter for Places of Cultural Significance, the adaptation or adaptive reuse means changing one place to suit the current use or proposed use where the user can be defined as the function of the site that including the activities, traditional and customary practices that can occur at that place or will be dependent on that place (Burra Charter, 2013).

The increment in the number of abandoned and derelicts building in Klang Valley has been a well-discussed issue for the nation. To overcome this problem, the authority to find a way to revive the building, due to that, the building is given a new life through a new lease and transformed into modern and trendy use hence attract people. The adaptive reuse approach involves repurposing the old building for current needs, which it managed to stand in today's world, while the historical value is retained and maintain. With this adaptive reuse, it helps to minimise the urban sprawl while conserving the existing resources, and at the same time, we managed to preserve our built heritage (Veldpaus et al., 2019)

Adaptive reuse should have a very little or minimum impact on the significance of the heritage itself and its setting. Furthermore, adaptive reuse is an act of self-defeating for the building if it fails to protect the heritage value (Ma \& Min, 2017). The best practice for adaptive reuse of heritage building is the projects that retain and respect the building's heritage significance value and add additional value to the future. Likewise, adaptive reuse is the way that can care for the fabric, interpreted and making better use for the building.

The adaptive reuse sometimes comes into action when the building is no more extended function as an original use; hence the adaptation is the only way to preserve the structure and retain its heritage significance value. For instance, in Australia, the policies enforced contain the standard criteria that ensure adaptive reuse has a minimal impact on the heritage building (ibid). The usual measures are as follows:

Discouraging 'facadism' which gutting the building while retaining its façade.

Requiring new work to be recognised as a contemporary, rather than have a poor imitation of the original historic style on the building.

Seeking the further use on the building that is compatible with the initial use.

\subsection{Benefits of Adaptive Reuse}

There are numerous benefits of adaptive reuse. The adaptive reuse of building plays a vital role in sustainable development. The adaptive reuse involves historic buildings; the environmental benefits are more significant, as the facility offers more towards the landscape, identity, and amenities of the communities they belong to. In the social aspect, keeping and reusing historic buildings has a long-term benefit. The adaptive reuse helps to restore and maintain the heritage significance of the building and ensure survival.

There are several financial savings and return can be made from the adaptive reuse in the economic aspects. There are energy cost savings from not demolished the building. As stated by Peter Bullen and Peter Love (2011), adaptive reuse is the most effective strategy to optimise the operational and commercial performance towards the built assets. The adaptive reuse also enables the building to suit new usage. Hence, it not only helps in rehabilitating the building, but it also helps in revitalisationrevitalising the neighbourhood, especially the old city, in the aspect of social and economic factors (ljla and Broström, 2015). Apart from that, it promotes urban strengthening and encourages revitalisation efforts.

In the adaptive reuse project, the site location is one of the most significant advantages since the building is located in the city centre. It became the most visited area. The old building is often deteriorating and decay in some way, but since it is an old building, it is 
treasured for its historical significance value. It is unique in some way during that time which cannot be compared with today's modern building's design where it is a lack here and there.

\subsection{Issues regarding adaptive reuse}

Some issues may arise to adaptive reuse the old building is the building codes. It became the most significant barrier in terms of converting an old building to modern use. Other than that, safety and accessibility become the biggest concern with the old building (Shuhana and Hashimah, 2005). The facility, through the adaptive reuse, will undergo redesigning, which requires all precautions to be taken to ensure the new use can adapt well to the old building. In reusing the building, it needs to ensure it is safe and functioning well, and it is expensive to replace and upgrade. Hence, it became a barrier in the adaptive reuse of the old building.

There are often hidden costs, and unexpected issue will arise in the project. So, early planning will ensure the process went smoother. The choice in choosing the contractors, architects, and engineer will help to save money and time. Hence the issues can be addressed early before signing an agreement. Based on Dilantha De Silva \& Kanchana Perera (2016), several issues may arise due to adaptive reuse. There are many direct and indirect cost of conservation involved in adaptive reuse in terms of economic considerations. The price may increase without our consciousness. Despite that, the high maintenance cost will affect the old building undergoing adaptive reuse. There is a considerable cost for maintenance and repair due to physical deterioration and defects. Besides that, nonavailability and incompatibility of new materials and lack of skilled workers in the conservation work also may affect the adaptive reuse program towards the old building (Silva and Perera, 2016).

\subsection{The heritage area of Petaling Street}

Petaling Street (PS) is listed as a secondary heritage zone by the Kuala Lumpur City Council along with Bukit Nanas and Pekan Sungai Besi. The areas are less contiguous compare to primary heritage zone, and it contains the mixture of newer and older buildings with significant historical merits. These areas consist of original historical shophouses and detached building typology that are a relatively small part of the land (Draft Kuala Lumpur Structure Plan 2020, 2018). Nonetheless, Said and Ahmad Hamzah (2020) commented that in Petaling Street, a uniform action needed in promoting a more prominent attraction to the adapted buildings to gain a bigger audience.

Petaling Street has been known for a vital trading area and remained until now. Over the years, the Chinese cultures in Petaling Street were swept away by the new generations and activities. Old shophouses doing traditional business with residential at the back of the shops are slowly turning into hotels or left empty. The human and culture values in this area are slowly disappearing upon the growth of the city. The apparent change in demographic could be seen recently where most of the population are made up of foreign workers from Bangladesh, Vietnam and Nepal. Sadly, some of them work without permits (Fong, 2018). With regards to that, a suitable conservation strategy is essential in maintaining the heritage value of that particular area to make sure the future generation able to understand and look into the past by bare eyes, not only by books or images.

\subsubsection{Merchant's Lane}

The Merchant's Lane is located at Lot 150, Petaling Street, Kuala Lumpur and this shop take up the entire first floor of the shophouse. The landmark of this shophouse is the green door, and it is located next to the stationary shop, Pemborong Alat Tulis Kiat Leong Stationery \& Trading. This stationery shop is on the ground floor while the Merchant's Lane is on the first floor. Merchant's Lane current owners are Ken Ho, Jun Ong, Kyle E and Kenneth Tan. During the 1980s, this shop served as a brothel, and later, it served as a hostelrenting room for immigrant workers.

This shophouse has been abandoned for five years before the founder takes this shophouse. According to Ken Ho, their design philosophy for Merchant's Lane are 'maintaining as much of the original structure and appearance as possible. We want it to showcase the heritage while having a modern facelift of sorts'. The adaptive reuse has transformed this once abandoned building to a 'hipster cafe' that offers local delicacies. Nonetheless, the rustic, heritage ambience is still in the present (Figure 1).
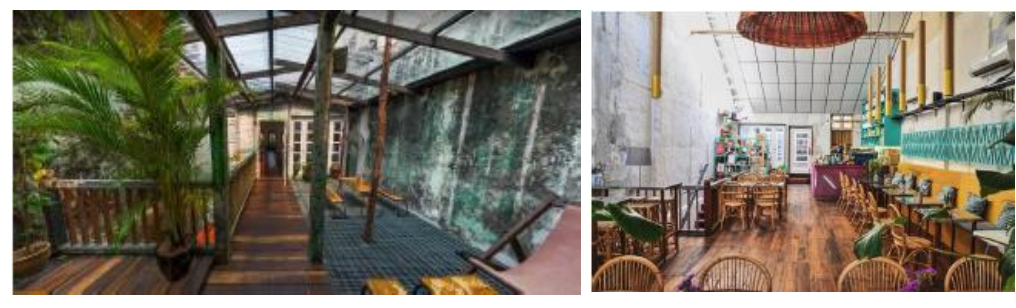

Fig.1: Merchant's Lane transformation from a brothel to a coffee house Source: Author, 2019 


\subsubsection{PS150}

PS150 was a brothel, later as a house, warehouse, and it is PS150 cafe today. It is next door to Merchant's Lane and located hidden behind a bookstore and toy shelf. According to the founder, Angel Ng, the PS150 recreates Chinatown's in three different eras, namely Opium-Den, inspired by the prohibition era in the 1920s in the US. The building can accommodate ten people.
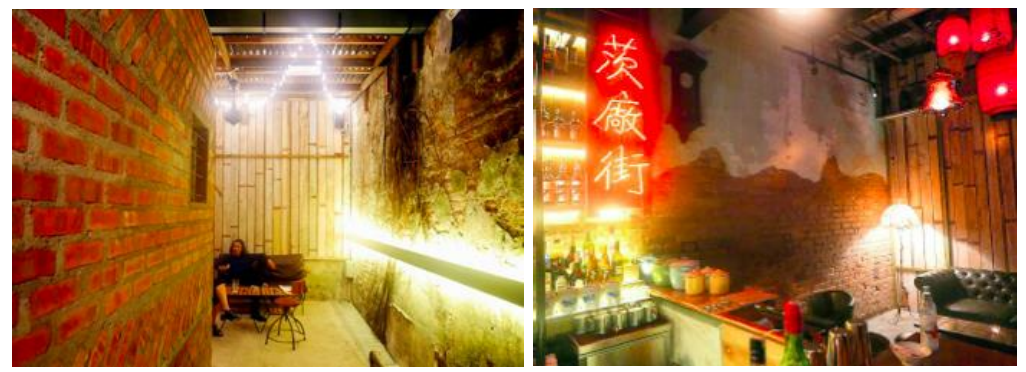

Fig.2: Opium den concept of PS150

Source: Author, 2019

The current adaptive reuse scheme tried to retain most of the heritage ambience of the place. Inspired by the opium den concept, most of the wall were bared, highlighting the original red bricks. This building has an open courtyard where a larger number of the customer were seated.

\subsubsection{Cocha Foodstore}

The Chocha Foodstore was a brothel and now repurposed as a café. The façade and interior design are retained but only change the usage of the shop-houses for modern needs. (Lazaroo, 2017). This 1920's heritage building situated at Lot 156, Petaling Street, Kuala Lumpur was a former Mah Lian Hotel at the front, but it served as a brothel at the back portion. The definition of Chocha is in the Hakka dialect, means 'sit' and 'tea' (ibid).

In 1969, this building was renovated by Mah Lian Hotel, to fit the usage as a hotel. The façade is adorned with tiny vintage tiles, which is the original walls since 1969. The building was later converted into staff lodging (hostel) before it was abandoned for ten years from 2007 to 2017. It was then rotted due to the abandonment and become dilapidated.
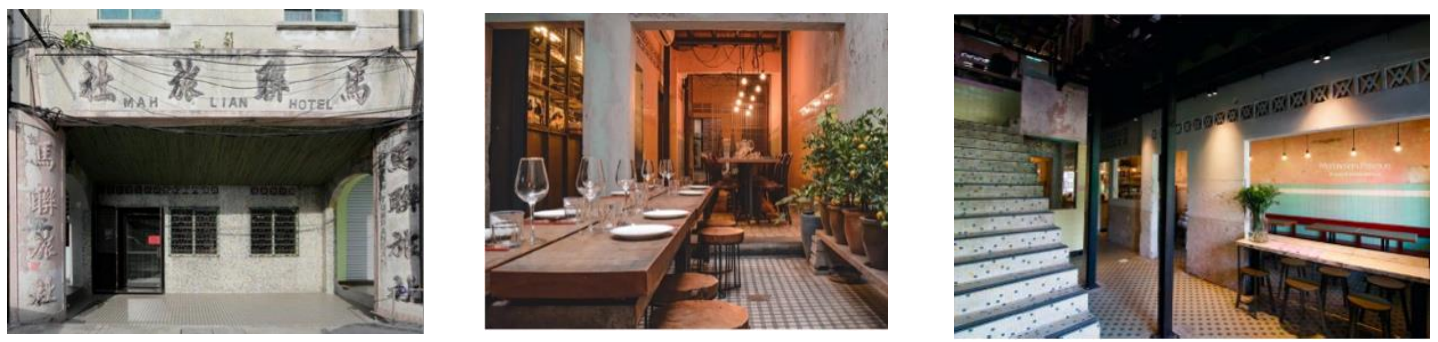

Fig.3: Minimal approach to the adaptive reuse of Mah Lian Hotel Source: Fatin Najmee, 2019, Hello Raya.com (2020)

The changes made to the building is minimal, and the 1969's renovation made good and could be seen today. The open courtyard and narrow buildings are fully utilised for dining tables. A minimal approach to the work kept the heritage ambience at the place.

\subsection{METHOD}

This research is a qualitative research where observations and interviews were carried out to collect essential data for the findings. The secondary data is the exploratory and investigatory that gain from the journal and research from another researcher. The qualitative data were obtained via an interview with the officers of the relevant department in order to achieve the objectives and aims of the dissertation. The interview was carried out with respondents from the relevant departments from Kuala Lumpur City Hall. The limitation for this study is when pandemic hits. Fieldwork was stopped and it takes longer time for questionnaire survey to be carried out. Fortunately, with the advancement of technology, questionnaire survey was carried out digitally using QR code. The code was placed at the counter of three Shophouses with the consent from the owner. Respondents scanned and answer the questions online.

The questions and observation are made pertaining to three case studies; Merchant's Lane, PS150 and Chocha Foodstore (Figure 4). These three adaptive reused shop houses attracted many tourists and visitors. The Questionnaire Survey was carried out with 87 responds. The respondents are users of the repurposed buildings. Questions were on their perceptions of the changes and how it affected their daily lifestyle. 
Interviews with a representative of Jabatan Warisan Negara (JWN)- the primary stakeholder for heritage conservation and protection and the local authority (Dewan Bandaraya Kuala Lumpur) were to get an insight of the guidelines used for the adaptive reuse of shophouses and how it helps in keeping the heritage intact.

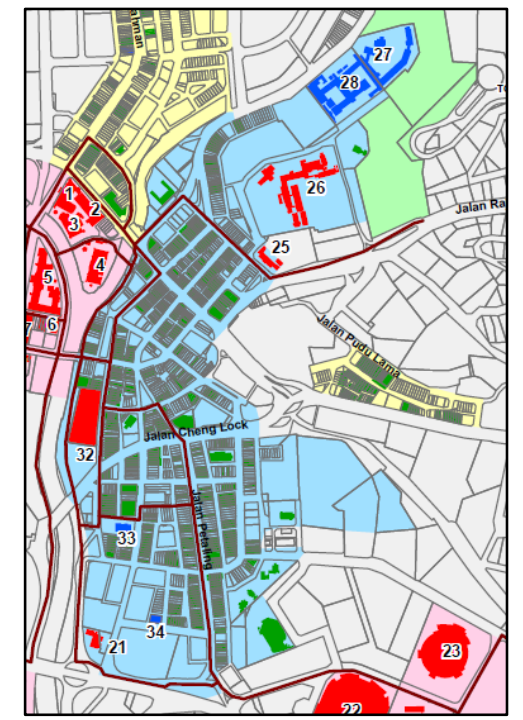

Fig.4: Map showing Petaling Street (blue) as part of the Secondary Heritage Area in KL City Plan 2020. Source: Kuala Lumpur City Plan 2020

Data gathered during the interview session is very important for the next stage of data collection. Site visit and observation of the selected case studies were carried out. Checklist of adaptive reuse guidelines was used to record the changes made, whether following the intended guidelines or not. The list was formed from the data gathered earlier. Data was analyzed based on the objectives of the study. The analysis provides answers to conclude the research.

\subsection{Results and Discussion}

\subsection{The requirement, concept, criteria and element of adaptive reuse required by the local authority}

In Malaysia, the guidelines for adaptive reuse were provided by the local authorities. The policies are basically focused on approaches of minimal changes in heritage buildings and modern intervention that is allowed in the process. Through document analysis and interview carried out with the officers in charge, the guidelines for adaptive reuse of heritage buildings in Kuala Lumpur have divided into eleven (11) criteria.

From the general observation carried out on-site, most of the buildings in Kuala Lumpur tried to adhere to the guidelines as much as possible. Every application for adaptive reuse of heritage buildings in Kuala Lumpur needs to go through the application for temporary change on building use. The application that includes the plan for change will be reviewed by the Design Review Panel for the suitability of service and conformation on the conservation standards by the National Heritage Department. The application then will go through the meeting of One-Stop Committee Review Panel and sent to Department of Building (Kuala Lumpur City Council) upon approval and will be given a work permit. The enforcement for the compliance of the guidelines will be carried out by the department.

\subsection{Compliance of the guidelines}

On site observation for the three case studies produces result as below:

Table 1: Compliance of Guidelines for Adaptive Re-use of Shophouses based on the criteria

\begin{tabular}{|c|c|c|c|c|c|}
\hline No & $\begin{array}{l}\text { REQUIREMENT } \\
\text { AND CRITERIA }\end{array}$ & ELEMENTS & $\begin{array}{l}\text { MERCHANT'S } \\
\text { LANE }\end{array}$ & PS150 & $\begin{array}{c}\text { CHOCHA } \\
\text { FOODSTORE }\end{array}$ \\
\hline \multirow[t]{4}{*}{1} & \multirow[t]{4}{*}{ Adaptive Re-Use } & $\begin{array}{l}\text { i. Respect the architectural and historical significance of the heritage } \\
\text { building }\end{array}$ & 1 & 1 & 1 \\
\hline & & $\begin{array}{l}\text { ii. Not damage or cause further destruction to existing building structures } \\
\text { and fabric }\end{array}$ & 1 & 1 & 1 \\
\hline & & iii. Retain and restore the original building features & 1 & l & I \\
\hline & & $\begin{array}{l}\text { iv. Replace existing building materials with similar or the closest possible } \\
\text { materials of the same or equivalent profile, performance, design, colour or } \\
\text { texture }\end{array}$ & I & I & 1 \\
\hline
\end{tabular}


v. Comply with modern building requirements including fire safety and structural integrity

$2 \quad$ Building Facade $\quad$ i. Retain or restore original façade including traditional timber shutters balustrades and decorative features using traditional building material

ii. Reinstate altered façade to its original façade

iii. Retain and restore existing sliding and folding metal grille

iv. Advertisement boards with significant visual impact are not permitted

for display on building façade

\begin{tabular}{|c|c|c|c|c|c|}
\hline 3 & Building Height & $\begin{array}{l}\text { i. The height of the new and renovated shop lots should follow the plot } \\
\text { ratio of the area and its original building façade } \\
\text { should retained. (allowable maximum height is } 17 \text { storey) }\end{array}$ & 1 & 1 & 1 \\
\hline \multirow[t]{3}{*}{4} & \multirow[t]{3}{*}{ 5-Foot Walkway } & $\begin{array}{l}\text { i. Retain and restore original design of 5-foot walkway including arch way, } \\
\text { floor tiles and arcades }\end{array}$ & 1 & l & 1 \\
\hline & & ii. Clear from obstructions & 1 & 1 & 1 \\
\hline & & $\begin{array}{l}\text { iii. Reinstate existing walls, ceiling and floors that have been previously } \\
\text { altered }\end{array}$ & & & \\
\hline \multirow[t]{5}{*}{5} & \multirow[t]{5}{*}{ Roof } & $\begin{array}{l}\text { i. Retain and restore original roof main structure, jack roof, traditional } \\
\text { roofing materials, eaves and fascia board }\end{array}$ & 1 & 1 & 1 \\
\hline & & ii. Replacement of pitched roof with flat concrete roof is not permitted & 1 & 1 & 1 \\
\hline & & iv. The use of metal decking roof is not permitted & 1 & 1 & 1 \\
\hline & & v. Retain the existing jack roof & 1 & 1 & 1 \\
\hline & & $\begin{array}{l}\text { vi. Any replacement of original roof tiles shall be of same or closest } \\
\text { possible materials following the original roof profile and pitch }\end{array}$ & 1 & 1 & 1 \\
\hline \multirow[t]{3}{*}{6} & \multirow[t]{3}{*}{ Colour Scheme } & $\begin{array}{l}\text { i. Colour scheme shall match and harmonise with the building characters, } \\
\text { surrounding and streetscape }\end{array}$ & 1 & I & 1 \\
\hline & & $\begin{array}{l}\text { ii. Retaining original types of paint and colours of a building are } \\
\text { recommended }\end{array}$ & $\mathrm{x}$ & $\mathrm{x}$ & I \\
\hline & & $\begin{array}{l}\text { iii. The use of shellac over timber surface is permitted but requires regular } \\
\text { maintenance and repainting }\end{array}$ & 1 & 1 & 1 \\
\hline \multirow[t]{3}{*}{7} & \multirow[t]{3}{*}{ Floor } & i. Retain or restore existing floor level and original structural & 1 & 1 & 1 \\
\hline & & $\begin{array}{l}\text { ii. Retain or restore original traditional floor materials like timber, terra } \\
\text { cotta, terrazzo or mosaic }\end{array}$ & 1 & 1 & 1 \\
\hline & & $\begin{array}{l}\text { iii. Replacement or original timber floor at upper floors with concrete slab } \\
\text { is not permitted }\end{array}$ & 1 & 1 & 1 \\
\hline \multirow[t]{3}{*}{8} & \multirow[t]{3}{*}{ Signage } & $\begin{array}{l}\text { i. Retain or restore original traditional signage on building (stonework, } \\
\text { metal letters, Chinese characters or bamboo } \\
\text { blinds) }\end{array}$ & 1 & 1 & 1 \\
\hline & & $\begin{array}{l}\text { ii. Advertisement boards above entrance door, upper low wall, on front } \\
\text { beam, side columns or above 5-foot walkway }\end{array}$ & l & I & I \\
\hline & & iii. No big signage covering building façade. & 1 & 1 & 1 \\
\hline \multirow[t]{2}{*}{9} & \multirow[t]{2}{*}{$\begin{array}{l}\text { Electrical Conduits } \\
\text { And Pipe }\end{array}$} & $\begin{array}{l}\text { i. Installation of electrical conduit pipes on the external façade are not } \\
\text { permitted }\end{array}$ & 1 & 1 & $\mathrm{x}$ \\
\hline & & $\begin{array}{l}\text { ii. Electrical conduits and pipes shall be neatly installed with proper metal } \\
\text { clips }\end{array}$ & 1 & 1 & 1 \\
\hline \multirow[t]{5}{*}{10} & \multirow[t]{5}{*}{$\begin{array}{l}\text { Air Conditioning } \\
\text { Unit }\end{array}$} & $\begin{array}{l}\text { i. Installation of air-conditioningpipes and conduits on the external building } \\
\text { facades shall not be permitted }\end{array}$ & $\mathrm{x}$ & 1 & 1 \\
\hline & & $\begin{array}{l}\text { ii. Installation of air-conditioning pipes on the surface of rear wall shall be } \\
\text { permitted }\end{array}$ & 1 & l & I \\
\hline & & iii. Air-conditioning pipes shall be properly encased and neatly installed & $\mathrm{x}$ & 1 & 1 \\
\hline & & $\begin{array}{l}\text { iv. Air-conditioning compressor units shall be located least visible from the } \\
\text { exterior }\end{array}$ & & & \\
\hline & & v. Installation of compressor unit at front façade is not permitted & 1 & 1 & 1 \\
\hline \multirow[t]{2}{*}{11} & \multirow[t]{2}{*}{$\begin{array}{l}\text { Security } \\
\text { Surveillance }\end{array}$} & $\begin{array}{l}\text { i. External security surveillance and protection measures shall be placed } \\
\text { at locations of less obtrusive }\end{array}$ & $x$ & $x$ & $x$ \\
\hline & & ii. Internal Security Surveillance and protection measure shall be neatly & $\mathrm{x}$ & $\mathrm{x}$ & $\mathrm{x}$ \\
\hline
\end{tabular}

internal Security Surveillance and protection measure shall be neatly placed at porch or five-foot walkway

Source: Author, 2019

\subsection{Responses from the users on the adequateness of the changes}

The changes made to these three buildings generally adequate for the repurposing of the building. New uses for the three buildings are relevant to the need of the economy of the area. Nonetheless, there are some essential elements needed for the buildings in term of safety were not fulfilled. The three buildings do not comply with modern buildings requirements, including fire safety and structural integrity and do not provide internal and external security surveillance. These are the critical elements needed in modern days. Nonetheless, the repurposing of the three buildings are adequate and necessary for the area to sustain its heritage significance.

Table 2: Users perception on the adequateness of the changes of the three shophouses

USER'S PERCEPTION

Repurposing of the buildings

Adaptive reuse helps in providing business opportunities
NUMBER OF PERCENTAGE RESPONSES

$\begin{array}{ll}85 & 98.9 \\ 82 & 95.3\end{array}$




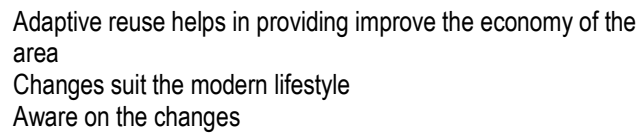

$\begin{array}{ll}82 & 95.3 \\ & \\ 85 & 98.9 \\ 64 & 74.7\end{array}$

Responses from the survey questionnaire in Table 2 indicate that $98.9 \%$ ( 85 respondents) agrees to the repurposing of the buildings. Eighty-two users feel that the adaptive reuse of the building helps in providing more business opportunities for Petaling Street and improve the economy of the area. 85 respondents think that the changes suit their modern lifestyle and increase the physical quality of the site. Even with the changes, users are aware that there are in a heritage area $(74.7 \%)$ and suggested for more repurposing to other types of uses such as Café (40.2\%), Hotel (28.7\%), Museum (16.5\%) and other services (14.6\%) (Table 3). Hence, it could be concluded that the adaptive reuse of heritage buildings in Petaling Street is welcome by the users and helps in regenerating the area in phases.

Table 3: Users suggestions on new usage of heritage Shophouses in Petaling Street

\begin{tabular}{lcc} 
PROPOSED NEW USAGE FOR BUILDINGS IN PETALING & NUMBER OF & PERCENTAGE \\
STREET & RESPONSES & \\
\hline Cafe & 35 & 40.2 \\
Hotel & 25 & 28.7 \\
Museum & 14 & 16.5 \\
Other services & 13 & 14.6 \\
\hline Total & 87 & 100
\end{tabular}

\subsection{Conclusion}

In conclusion, based on the data that has been obtained from the interview session and questionnaire survey, users agree to the changes taken place. The approach to adaptive reuse has suited their modern lifestyle and increase the quality of life of the people. Nonetheless, Petaling Street needs more regeneration initiatives in order for many more shophouses to be repaired and sustain. The result from the interview with the authorities indicates only small groups that have the ambition to retain the old building. The approach to conservation follows the guidelines, but not for the safety aspect and including some of the original material. It is known that the layout of the street and narrowness of buildings due to old design prevented the compliance of the guidelines.

Furthermore, adaptive reuse or repurposing of heritage buildings is a way to sustain the historic building while providing modern architectural design in the interior of the building to suit user needs and requirement. The approach is famous and in-demand, albeit the cost, but positively contributes to the improvement of the quality of life of the place. It also meets the demand of the growing population of Kuala Lumpur. It is suggested that a research on the effect of the changes to the socio-cultural activities of the Petaling Street to be carried out as an extension of this study,

\section{Acknowledgements}

This paper is a collaboration between UiTM and Universitas Bung Hatta in the research of heritage environment.

\section{Paper Contribution to Related Field of Study}

The study explores approaches to adaptation of usage of heritage buildings in Petaling Street. There are many potentials for heritage buildings to be use and appreciated in modern days with the correct approach to adaptive reuse. This paper will help in providing overview of current state of the scheme. The research is relevant to SDG11Sustainable Cities Communities: Make cities and human settlements inclusive, safe, resilient and sustainable

\section{References}

Basha, B. (2016). Viability of adaptive reuse with social approach: case study of Asia Heritage Row, Kuala Lumpur (Master's thesis, Gombak, Selangor: International Islamic University Malaysia, 2016).

Bullen, P and Love, P. (2011). Adaptive Reuse of Heritage Building: Sustaining an Icon or Eyesore. Retrieved form https://www.researchgate.net/publication/289542719_Adaptive_reuse_of_heritage_buildings_Sustaining_an_icon_or_eyesore

Burra Charter (2013) ICOMOS Burra Charter from https://australia.icomos.org/publications/charters/

De Silva, Dilantha \& Perera, Kanchana. (2016). Barriers and Challenges of Adaptive Reuse of Buildings. Institute of Quantity Surveyors Sri Lanka annual technical sessions 2016- "Social responsibility of Young Quantity surveyors"

Kuala Lumpur City Plan 2020: A World Class City. Dewan Bandaraya Kuala Lumpur. Retrieved from https://www.dbkl.gov.my/klmycity2040/?page_id=4311

Fong, F (2018) Nothing Chinese about Petaling Street anymore. Retrieved from https://www.nst.com.my/news/nation/2018/03/350498/nothing-chinese-about-petalingstreet-anymore 
Harun, S.N (2011). Heritage Building Conservation in Malaysia: Experience and Challenges. Retrieved from https://www.sciencedirect.com/science/article/pii/S1877705811029468

ICOMOS Australia (2013), The Burra Charter: The Australia ICOMOS Charter for Places of Cultural Significance 1999: With Associated Guidelines and Code on the Ethics of Co-existence, ICOMOS, Burwood.

lila, A. and Broström, T. (2015), "The sustainable viability of adaptive reuse of historic buildings: the experiences of two world heritage old cities; Bethlehem in Palestine and Visby in Sweden", International Invention Journal of Arts and Social Sciences, Vol. 2 No. 4, pp. 52-66.

Lazaroo, S (2017) KL's Chocha Foodstore offers modern Asian cuisine in conserved building that used to be a brothel. Retrieved from https://www.straitstimes.com/lifestyle/travel/kls-chocha-foodstore-offers-modern-asian-cuisine-in-conserved-building-that-used-to

Said, S.Y., \& Ahmad Hamzah, S.N.A (2020) Impact of Urbanization On Cultural Identity and Townscape Characteristics of Kuala Lumpur China Town, Malaysia. WIT Press

Shazwan, M.K (2016) For Petaling Street, the continuing tussle between its fading past and urban revival. Retrieved from https://www.malaymail.com/news/malaysia/2016/10/15/for-petaling-street-the-continuing-tussle-between-its-fading-past-and-urban/1228143

Shishavan, S. N., \& Shishavan, M. N. (2013). Comparative investigating of adaptive reuse and sustainable architecture with social approach. ALAM CIPTA, International Journal of Sustainable Tropical Design Research and Practice, 6(2), 101-111.

Teng, Yip Yoke (2018) Revival of KL's Chinatown. The Star Online. Retrieved from https://www.thestar.com.my/metro/metro-news/2018/05/30/revival-in-kls-chinatownnew-investors-do-their-part-to-save-petaling-streets-prewar-structures-with/

Tony, Ma \& Yu, Minmei. (2017). An Analysis of the Adaptive Re-use of Heritage Buildings in South Australia. 10.1007/978-981-10-0855-9_114.

UNESCO (2019) UNESCO Culture for Development Indicators. CDIS Manual v7. Retrieved from: https://en.unesco.org/creativity/sites/creativity/files/cdis/heritage_dimension.pdf

Veldpaus, L., Fava, F. \& Brodowicz, F (2019) Organizing, Promoting and Enabling Heritage Re-use through Inclusion, Technology, Access, Governance and Empowerment. Open Heritage: European Union (Deliverables 1.2 Report: Mapping of current heritage re-use policies and regulations in Europe Complex policy overview of adaptive heritage re-use)

WBDG (Whole Building Design Guide) Historic Preservation Subcommittee (2019) Historic Preservation. Retrieved from Shttps://www.wbdg.org/designobjectives/historic-preservation 